\title{
Life cycle assessment in corporate sustainability reporting: Global, regional, sectoral,
} and company-level trends

Stewart, Raphaëlle Marie Marianne; Fantke, Peter; Bjørn, Anders; Owsianiak, Mikoaj; Molin, Christine; Hauschild, Michael Zwicky; Laurent, Alexis

\section{Published in:}

Business Strategy and the Environment

Link to article, DOI:

$10.1002 /$ bse. 2241

Publication date:

2018

Document Version

Peer reviewed version

Link back to DTU Orbit

Citation (APA):

Stewart, R. M. M., Fantke, P., Bjørn, A., Owsianiak, M., Molin, C., Hauschild, M. Z., \& Laurent, A. (2018). Life cycle assessment in corporate sustainability reporting: Global, regional, sectoral, and company-level trends. Business Strategy and the Environment, 27(8), 1751-1764. https://doi.org/10.1002/bse.2241

\section{General rights}

Copyright and moral rights for the publications made accessible in the public portal are retained by the authors and/or other copyright owners and it is a condition of accessing publications that users recognise and abide by the legal requirements associated with these rights.

- Users may download and print one copy of any publication from the public portal for the purpose of private study or research.

- You may not further distribute the material or use it for any profit-making activity or commercial gain

- You may freely distribute the URL identifying the publication in the public portal 
Stewart et al. (2018) Business Strategy and the Environment

DOI: 10.1002/bse.2241

\title{
Life cycle assessment in corporate sustainability reporting: Global, regional, sectoral and company-level trends
}

\author{
Authors: Raphaëlle Stewart ${ }^{1,2^{*}}$, Peter Fantke ${ }^{1}$, Anders Bjørn ${ }^{3}$, Mikołaj Owsianiak $^{1}$, Christine Molin ${ }^{1}$, \\ Michael Zwicky Hauschild ${ }^{1}$, Alexis Laurent ${ }^{1}$ \\ ${ }^{1}$ Division for Quantitative Sustainability Assessment, Department of Management Engineering, Technical \\ University of Denmark, Bygningstorvet, Building 115-116B, 2800 Kgs. Lyngby, Denmark \\ ${ }^{2}$ Department of Design, Norwegian University of Science of Technology, Kolbjørn Hejes Vei 2b, 7491 \\ Trondheim, Norway
}

${ }^{3}$ CIRAIG, Polytechnique Montréal, Department of Mathematics and Industrial Engineering, 3333 chemin QueenMary, Bureau 310, C.P. 6079 Montréal, Canada

*Corresponding author: rste@dtu.dk

\begin{abstract}
Large companies now commonly release corporate sustainability (CS) reports, in which they describe their approach to handle sustainability challenges. To guide environmental sustainability efforts in industry, the Life Cycle Assessment (LCA) methodology has been recognized as an important tool by researchers and policy-makers. But to what extent has the LCA methodology been present in companies' narratives through their CS reports up to now? To answer this question we map references to the LCA methodology in CS reports over the past two decades at geographical, sectoral and company levels through keyword searching within an extensive database (ca. 45000 CS reports); analyze trends; and highlight challenges, opportunities, and recommendations to strengthen the presence of LCA in CS reports. The results show that LCA generally remains weakly present in CS reporting, with some geographical and sectoral variations. Recommendations to strengthen LCA presence in CS reports are derived for method developers, policy-makers and companies.
\end{abstract}

\section{Keywords}

LCA; environmental assessment; CSR report; environmental management; environmental strategy; Corporate Register 


\section{Introduction}

The United Nation's (UN) Sustainable Development Goals (SDGs) chart a direction for global sustainability efforts in the coming decades (UN, 2015). Specifically, SDG number 12, aiming to "ensure sustainable consumption and production patterns", puts renewed attention to the role of business in sustainable development. Companies should proactively tackle the environmental issues related to their activities. Within their environmental sustainability strategies, businesses are expected to scrutinize their supply chains and life cycles of their products and seek to mitigate their associated environmental impacts (Comas Martí and Seifert, 2013; Pflieger et al., 2005).

Life cycle thinking is one of the dominant approaches to understand the environmental sustainability performance of systems, prescribed in scientific research, as well as in industry initiatives, standards and policies (Seuring, 2004; EU-JRC, 2010; Lehman et al., 2015; Dyllick and Rost, 2017). A variety of life-cycle based indicators covering different environmental impacts, such as carbon footprint and water footprint, have been developed to quantify the environmental performance of organizations or products and inform companies' environmental strategies (Laurent and Owsianiak, 2017). The Life Cycle Assessment (LCA) methodology provides a comprehensive account of potential environmental impacts, by covering all relevant environmental issues associated with the life cycle of an assessed product or service system, i.e. from the extraction of the raw materials through manufacture and use or operation up to the final disposal (ISO, 2006). Through intensive harmonization and standardization efforts, LCA has evolved into a robust methodology to assess the environmental impacts associated with a given system (ISO, 2006; Finnveden et al., 2009; Goedkoop et al., 2015). An increasing utilization of LCA in industry has been suggested (e.g. Goedkoop et al., 2015; Finkbeiner, 2016) and the use of this methodology has been promoted in various policy-making initiatives (Sonnemann et al., 2018). For example, at the EU level, LCA has been listed as one of the tools within the EU "Better regulation toolbox" to develop future regulations and adjust existing ones in Europe (EC, 2015). The development and testing of the LCA-based Product Environmental Footprint (PEF) and Organization Environmental Footprint (OEF) methodologies for application in industry has also been ongoing for the past years at the European level (EC, 2016; 2018a).

Within their corporate sustainability (CS) efforts, large companies now commonly release CS reports as part of their reporting cycles (Kolk, 2003; Siew, 2015; KPMG, 2015). The publication of CS reports is increasingly required by regulations (EC, 2014; KPMG, 2015; Ernst and Young, 2014), and the number of companies publishing CS reports was actually proposed as an indicator to monitor the SDG target 12.6 to "encourage companies, especially large and transnational companies, to adopt

sustainable practices and to integrate sustainability information into their reporting cycle" (UN, 2017). CS reports are defined as "public reports by companies to provide internal and external stakeholders with a picture of corporate position and activities on economic, environmental and social dimensions" (WBCSD, 2002). In CS reports, companies provide narratives of their sustainability efforts in order to meet their stakeholders' demands for higher transparency on sustainability matters (Lozano, 2016). CS reporting is an important communication tool for companies, both internally, as it aims to bring visibility on and increase employees' awareness of sustainability efforts (Searcy and Buslovich, 2014) 
and externally, by providing investors and rating agencies with an account of their sustainability practices and performance (Hezig and Schaltegger, 2006).

Only few studies exist on the link between LCA and CS reporting. Pflieger et al. (2005) suggested following the LCA methodology to further develop CS reporting away from its direct organizational focus, with higher focus on product-related information, and on providing information about environmental impacts beyond material and energy flows. Kaenzig et al. (2014) compared the environmental information disclosed in CS reports by companies with the environmental impacts from LCA studies of their products. They found that often only a limited share of the total environmental impacts of products was included in quantitative environmental disclosures present in CS reports because they did not take a life cycle perspective. Nygren and Antikainen (2010) explored the reference to LCA in the public communications, including CS reports, of twenty multinational company frontrunners belonging to diverse sectors and found that these companies generally reported a use of the LCA methodology and other life cycle-based practices. Earlier work has explored companies' sustainability practices based on their CS reports and revealed a life cycle approach in efforts of companies. For instance, Comas-Martí and Seifert (2013) explored the extent to which CS strategies considered the life cycle of the companies' products; Kozlowski et al. (2015) found that apparel companies indicated activities such as ecodesign, supplier monitoring programs or take-back systems which reflect life cycle thinking.

However, the extent to which companies refer to the LCA methodology in their narratives of sustainability efforts remains unclear. Exploring sustainability approaches of companies through the lens of their CS reports can be viewed as meaningful because they show "firms' understanding of how their environmental strategies should be 'best' presented" and they reveal "what each company believes to be its key messages" (Mikler, 2007, p. 14). For instance, Landrum and Ohsowski (2017) explored how companies' view sustainability based on their CS reports. In this perspective, the present study aims to investigate the presence of the LCA methodology in companies' narratives of their sustainability efforts in CS reports. Our research objectives are (i) to map the presence of LCA in CS reports at global and regional geographical scale and at the level of sector or company over the past two decades using keyword searching within an extensive database of CS reports; (ii) to analyze the observed trends in presence of LCA in CS reports in the light of development of the LCA methodology and its promotion by policy-making, research and industrial initiatives; (iii) to highlight possible challenges to the reporting of LCA in CS reports and opportunities associated with LCA presence in CS reports and (iv) to provide recommendations to strengthen the presence of LCA in CS reports.

In the following sections, we first present relevant background insights into LCA and CS reporting (Section 2). We then introduce the methodology used to perform the study (Section 3), including a description of assumptions and uncertainties, before presenting (Section 4) and discussing (Section 5) the results, together with the main limitations of the study and practical recommendations. Finally, conclusions are drawn and an outlook is presented for future research (Section 6). 


\section{Background}

\subsection{Life cycle assessment in industry}

The LCA methodology was formalized at the beginning of the 1990s by the Society of Environmental Toxicology and Chemistry (SETAC) (SETAC, 1991) and standardized with the ISO14040-44 series (ISO, 2006) in the late 1990s, which pushed its promotion at a global level (Töpfer, 2002). From an original focus on assessing product or service systems, recent developments have broadened the scope of LCA applications, and opened it to assess organizational systems, lifestyles and countries (Hellweg and Milà i Canals, 2014). LCA has been the subject of intensive academic research and scientific publications on LCA have grown exponentially over the past years especially in Europe and North America (De Souza and Barbastefano, 2011; Chen et al., 2014; Hu et al., 2015).

Launched in 2002, the UNEP/SETAC Life Cycle Initiative has been working towards building an expert community of practitioners and reaching the worldwide dissemination of the LCA methodology and life cycle thinking among business, governments and consumers through its different working groups (Töpfer, 2002; Bjørn et al., 2018; Sonnemann et al., 2018). Regional LCA networks have flourished over the past 20 years, especially in the EU and North America (Bjørn et al., 2013). In North America, industrial initiatives such as the American Center for Life Cycle Assessment launched in 2001 and the Sustainability Consortium launched in 2009 (ACLCA, 2017; The Sustainability Consortium, 2017) also push the LCA agenda. In a European context, various EU recommendations and guidelines for sustainability approaches in industry pull from the LCA methodology, including the Integrated Product Policy directive (EC, 2003), the directive on the eco-design of energy using products in the EU region (EC, 2009), the eco-labelling scheme (EC 2010), the EU better regulation toolbox (EC, 2015) as well as the Product Environmental Footprint (PEF) and Organization Environmental Footprint (OEF) guidance documents (EC, 2016; 2018a). Type III environmental information on products, in the form of Environmental Product Declarations (EPD) (Ibanez-Fores et al., 2016), are directly associated with conducting an LCA following a set of product categories rules. Type I eco-labeling of products does not require the conduction of LCAs; yet, a type I eco-labeled product must fulfill a number of requirements along its life cycle.

The basic rationale for conducting LCA at companies is to quantify where the largest environmental impacts occur in their products' life cycles, and see how they can address them through conscious design decisions and collaborations with relevant value chain players (Owsianiak et al., 2018). Earlier studies on the uptake of LCA by industries have revealed that companies use LCA to identify environmental hotspots (Frankl and Rubik, 2000), inform and educate consumers and stakeholders (Frankl and Rubik, 2000; Cooper and Fava, 2006), compare existing products with planned alternatives (Frankl and Rubik, 2000), support product development activities (Frankl and Rubik, 2000; Cooper and Fava, 2006); inform and drive strategic decisions; improve the internal monitoring systems and make robust communication of green attributes to market stakeholders (Testa et al., 2016). A number of challenges faced by companies in the adoption of LCA have also been identified. Recurrent challenges include the complexity, time and cost of conducting LCAs, especially in relation to the collection of data, hiring of consultants or purchase of software (Schaltegger, 1997; Cooper and Fava, 
2006), as well as the challenges and uncertainties related to interpreting and communicating the results (Testa et al., 2016).

In the early years of the methodology, Berkhout (1996) reported that its adoption in industry started in Europe and followed in North America and Asia. The early adoption of LCA was indicated to be particularly important in the Nordic region in the late 1990s (Hanssen, 1999). In these early years, packaging materials and consumer products were common sectors for applications (Gloria et al, 1995; Berkhout, 1996; Hanssen, 1999; Hauschild et al., 2005). The electronic goods, automobiles, chemicals, aluminum, food and paper industries are also historical sectors of application (Berkhout, 1996; Berkhout and Howes, 1997). In the late 1990s, the service industry was reported to be little involved in LCA activities due to a lack of regulatory incentives, applicable metrics and approaches to evaluate the environmental impacts associated to a service (Graedel, 1997; Baumann, 1996). Frankl and Rubik (2000) surveyed Italian, Swedish, German and Swiss companies for their adoption of LCA and found adoption of up to $40-45 \%$ among the largest companies, as well as indications that an increasing use of the methodology was planned in more than half of the surveyed companies. More recently, Hörisch et al. (2015) surveyed the use of diverse sustainability management tools in 186 large North American, Japanese, Spanish and South Korean companies in 2012, and found that nearly $50 \%$ of them indicated using LCA-based tools. A recent study of EPD practices show that the building and the food and beverage sector were particularly active in issuing EPDs (Ibanez-Forés et al., 2016). In a recent study based on a survey of 800 large European companies, Chiarini (2014) found that both service and manufacturing companies acknowledged the ability of LCA to effectively improve the environmental performance of their supply chains.

\subsection{Corporate sustainability reporting}

CS reports vary between companies in terms of coverage of sustainability aspects and reporting quality (Hahn and Kühnen, 2013), but they typically provide an account of practices for a selection of sustainability issues considered important or relevant by the company, including information on the tools and indicators used to address and measure the selected sustainability issues (Montabon et al, 2007; Roca and Searcy, 2012; Siew, 2015). CS reporting increasingly follows voluntary standards, with the Global Reporting Initiative (GRI) reporting framework (GRI, 2013) being the most popular voluntary reporting reference for companies worldwide (KPMG, 2015). CS reports contain a mix of organization and product-level disclosures (Comas-Marti and Seifert, 2013). Within the list of standard environmental disclosures recommended by the GRI 4 framework, 29 of them are framed at the organizational level while only 5 are defined at a product or service level (GRI, 2013). Traditionally, CS reports have been released by large companies, whereas smaller companies have been hindered by a lack of resources and adequate guidelines (Borga et al., 2009).

Earlier works on sustainability reporting have shown that CS reports play both external and internal roles (Pérez-López et al., 2015). From an external perspective, CS reporting is an instrument used by ranking agencies and investors to assess and compare CS efforts in industry (Herzig and Schaltegger, 2006). From an internal perspective, CS reporting has been found to serve as guidance to initiate sustainability work at companies (Hedberg and van Malmborg, 2003), to improve employee awareness and engagement by legitimating the company, celebrating progress, and bringing visibility 
of employee activities (Searcy and Buslovich, 2014), and to go hand in hand with organizational change for sustainability in a mutually reinforcing process (Lozano et al., 2016). On the other hand, various studies have questioned the extent to which CS reporting genuinely addresses sustainability issues and presents substantive actions from companies, as opposed to symbolic disclosures aimed at strengthening their corporate image and reputation (Hrasky, 2011; Milne and Gray, 2013; Tregigda et al., 2014; Gold and Heikkurinen, 2018).

\section{Methodology}

An overview is given of the overall methodology in Figure 1 with detailed description of the different steps in the following sections.

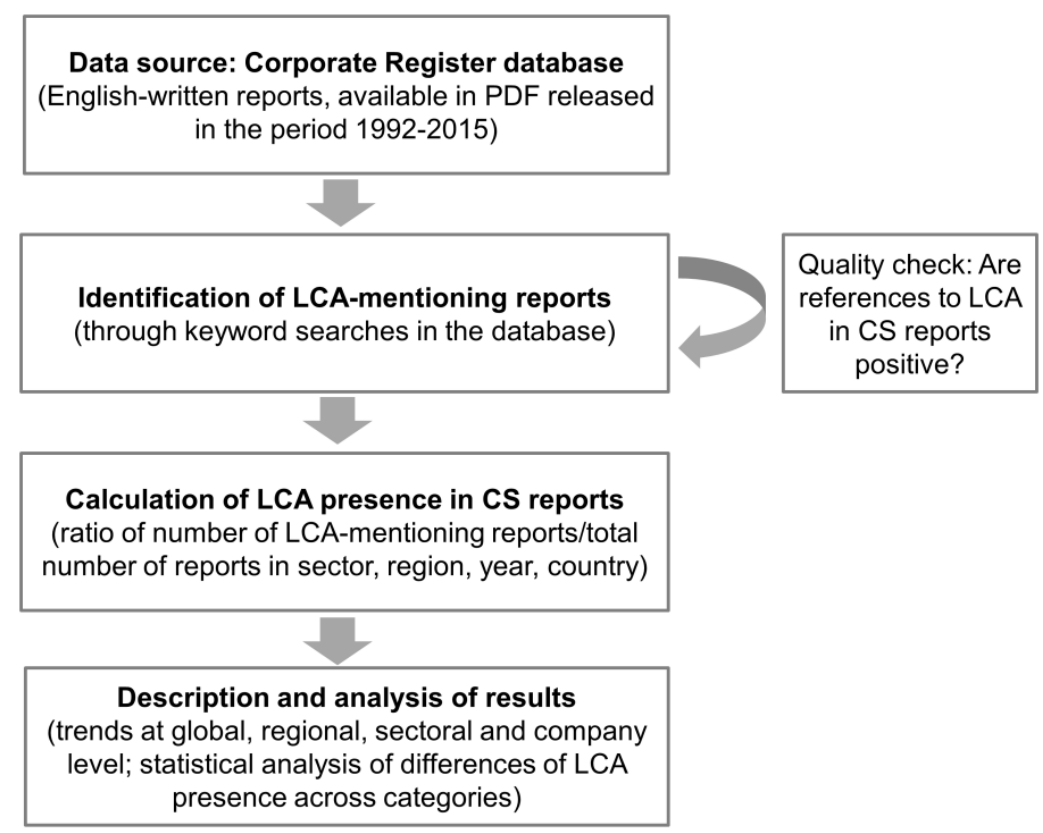

Figure 1. Overview of the methodological approach.

\subsection{Data sources for CS reports}

The study builds on a systematic mapping of LCA-related terms in CS reports. The names of these reports vary broadly and include among others "corporate sustainability reports", "citizenship reports', "Corporate Social Responsibility (CSR) reports", "sustainable development reports", and "environmental reports" (Roca and Searcy, 2012; Kolk, 2010). Hereafter, a report identified through any of the above-mentioned names is referred to under the term "corporate sustainability report" (CS reports).

The Corporate Register database, which is the largest online database of CS reports, was used to access publicly available reports (CR, 2017a). The database is reported to contain more than 80000 report entries associated to nearly 14000 companies since 1992 (CR, 2017a). It is estimated by its developers to cover more than $90 \%$ of all reporting companies and it is updated daily (CR, 2017b). A 
search engine is available on the website for conducting specific report content searches, as previously undertaken by Bjørn et al. (2017). Additionally it allows filtering reports by year, sector and country. The report search was conducted in the period August-November 2016 and covers all English-written CS reports available in PDF in the Corporate Register database (ca. 50000 CS reports). The database includes CS reports which were published between 1992 and 2016. The time period chosen in the study was 1992-2015, since CS reports released in 2016 were not all present in the database at the time of the study. Reports from governments, education and branch organizations were excluded to keep the sole focus on industry, leaving us with a total of ca. 45000 CS reports as a basis for the study.

\subsection{Identification of references to LCA in CS reports}

CS reports referring to LCA were identified by performing searches of LCA-related terms in the Corporate Register database using the embedded search function. Information about the CS reports containing LCA-related terms was collected, including report name, publishing company name, sector of the publishing company, country where the company's headquarter is located and report publication year. The list of LCA-related terms searched for was developed by the author team and included "life cycle assessment", "life-cycle assessment", "lifecycle assessment", "life cycle analys", "life-cycle analys" and "lifecycle analys". The acronym "LCA" was considered, but eventually not used as a search term, because it would identify non-relevant terms such as "volcanized rubber", and because companies were assumed to first use the full name of the methodology before its acronym. "Product Environmental Footprint" (PEF) and "Organization Environmental footprint (OEF) were not included in the search term list since the introduction of the PEF and OEF guidelines were still at a very early stage at the time of the report searches. Considering the scope of the present study and its focus on the LCA methodology, only synonyms of LCA were included in the keyword search, whereas other broader terms referring to life cycle thinking or life cycle management were omitted. The number of LCA-related terms per CS report could not be taken into account in the database search function. Thus, the mapping disregards potential differences in LCA content richness across CS reports. This is an inherent limitation of the present study and will require future explorative work.

The methodology relies on the assumption that LCA references, i.e. presence of a LCA-related term, in CS reports corresponds to a positive reference to LCA. False positive references include for example reports only listing LCA in the glossary, having LCA as a headline but not providing any more information, listing a reference to an LCA source while actually not addressing LCA in the text or mentioning LCA as a tool stated not to be used by the company. CS reports containing LCA-related terms that correspond to positive references are hereafter called LCA-mentioning reports. In order to test the representativeness of this number, a quality check was performed on a sample of 331 reports. Details about sampling are provided in the Supplementary Methods. The test resulted in $94 \%$ of positive references to LCA. This means that for a confidence level of 95\%, LCA references in reports correspond to positive references in $89 \%-99 \%$ of the cases. In the perspective of these results, the trends described in the following sections which are based on reports containing LCA-related terms are considered representative of LCA-mentioning CS reports. 


\subsection{Calculation of LCA presence in CS reporting}

Sectoral categorization of LCA-mentioning CS reports: we adapted the sector classification of Corporate Register, which is very similar to the Industry Classification Benchmark classification (ICB, 2017) (see Table S1 in Supplementary Methods).

Calculations of LCA presence in categories: The LCA presence in CS reports of a given category, e.g. a sector in a given year or a country in a given year, is defined as the ratio of LCA-mentioning CS reports in a category to the total number of CS reports in that category. These ratios were calculated based on the information collected for each LCA-mentioning CS report (country, sector and year) and on additional searches in the Corporate Register database which consisted in collecting the information on the total number of CS reports contained in the database for each category. The unit of analysis in all LCA presence calculations is the CS report, as opposed to the reporting company, due to limitations of the search function available with the database used.

\subsection{Description of trends and analysis}

The subsequent analysis was focused on describing and discussing temporal trends at global, regional, sectoral and company level. We performed two additional analysis steps for the sectoral trends which were deemed relevant in the light of existing literature about LCA adoption in industry. First we studied the influence of business activity type (manufacturing versus service sectors) and customer type (business-to-business (B2B) versus business-to-consumer (B2C) sectors) on LCA presence in CS reporting. The division into B2B/B2C and manufacturing/service sectors was performed based on the sector descriptions provided for the ICB structure (ICB, 2017) - see Table S2 in Supplementary Methods. Pearson's chi-square was used to statistically test the independence of sector categories (B2B/B2C and manufacturing/service classification) with regard to differences in LCA presence in CS reporting. The tests were conducted for business activity type separately for B2B and B2C sector subsets, and for customer type separately for manufacturing and service sectors subsets. The data used to conduct the test is presented in Table S4 in Supplementary Results. The pvalue threshold for independence of variables was set at $p=0.05$. Second we qualitatively compared LCA presence in CS reports and the distribution of environmental impacts in the supply chain across sectors.

\section{Results}

LCA-related terms were identified in 2367 CS reports, which means that the LCA-mentioning reports correspond to approximately 5\% of all English-written reports available as PDF in the Corporate Register database and published between 1992 and 2015 (data not shown; available upon request to the authors). These reports were published by 1167 unique companies in the period 1995-2015 (i.e. no LCA-mentioning CS reports in 1992-1994).

\subsection{Global trend}

As illustrated in Figure 2, the absolute number of LCA-mentioning CS reports published each year has overall increased since 1995, with a steep growth between 1995 and 2002, followed by a period of 
stagnation until 2007 and a new but slower growth since then. Relative to the total number of CS reports, LCA presence in CS reporting has undergone 3 phases: after a relatively high presence of LCA in CS reports in the 90 s, with approximately $15-20 \%$ of the total CS reports, the LCA presence has experienced a net decrease between 1999 and 2007 before stabilizing at ca. 5\% (see Fig. 2). This suggests that during the period 1999-2007, LCA has dropped on the CS reporting agenda, while an increasing number of companies were starting to release CS reports. Since 2007, references to LCA in CS reports have kept up with the increasing number of CS reports released by industry.

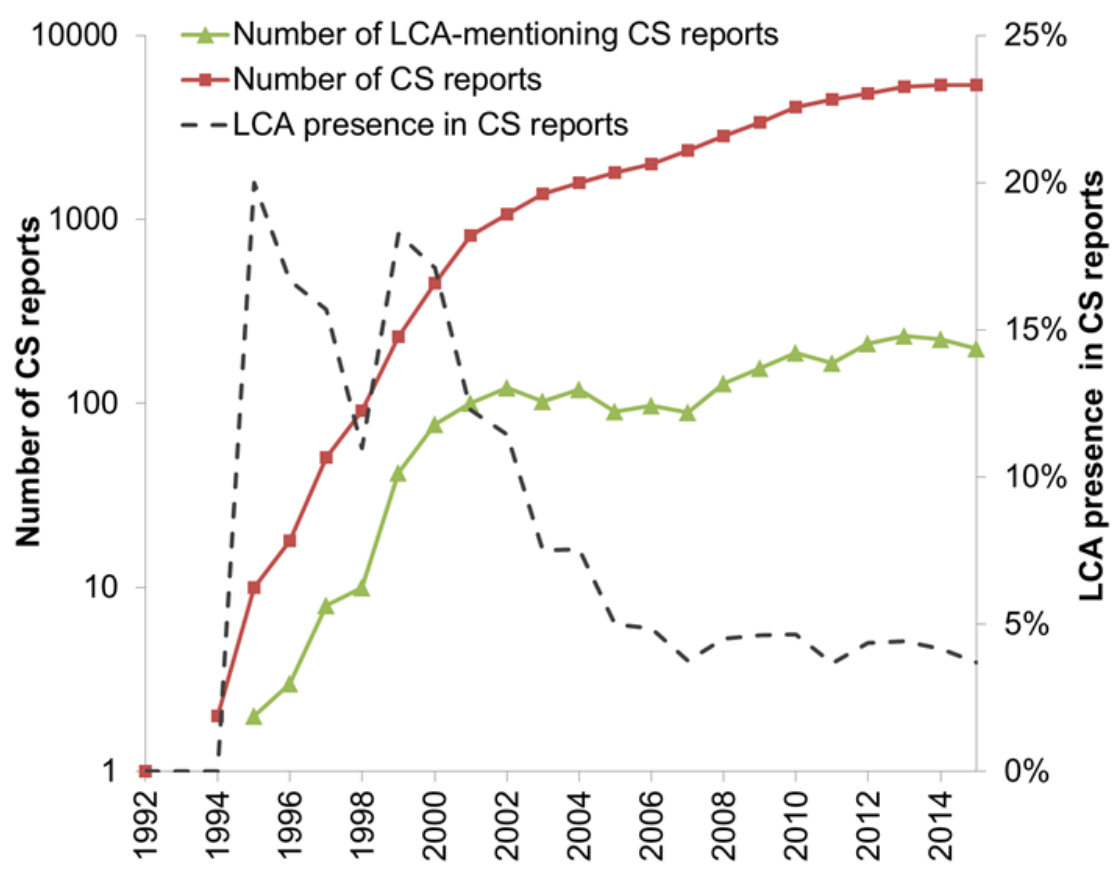

Figure 2. Temporal evolution in number of CS reports, LCA-mentioning CS reports (left y-axis) and LCA presence in CS reporting defined as the ratio between the two (right y-axis). Note the logarithmic scale on the left y-axis.

\subsection{Regional and national trends}

Figure 3a shows that since the late 1990s, CS reporting activities have overall increased in all regions, with the strongest developments being in Europe and North America, while the smallest are observed for Africa and South America. Figure $3 b$ reveals that the developments of LCA-mentioning reports have been the strongest in Europe and North America, while Japan shows a net decreasing trend followed by a recent stabilization. A slower start in North America than in Europe for LCA presence in $\mathrm{CS}$ reports can be seen on Figure $3 \mathrm{~b}$.

With respect to LCA presence in CS reporting, Figure $3 c$ confirms that North America and Europe are leading as of 2015 , with a rate of ca. $5 \%$. Various trends can be observed across the regions for LCA presence rates. In Europe and Japan, LCA presence in CS reporting has decreased from relatively 
high values (i.e. $20 \%$ for Europe; $40 \%$ in Japan in 2000) to stabilize at ca. 5\% in Europe since 2005 and ca. 2-3\% in Japan since 2013. In North America and Oceania the LCA presence in CS reporting has overall remained stable with an average presence of ca. $5 \%$. Because of the limited number of CS reports mentioning LCA up to 2005, the LCA presence in CS reports in Asia (excl. Japan) shows series of spikes before stabilizing at ca. 2-3\% from 2005 and on. In Africa and South America, LCA presence in CS reporting has remained very low over the entire period.
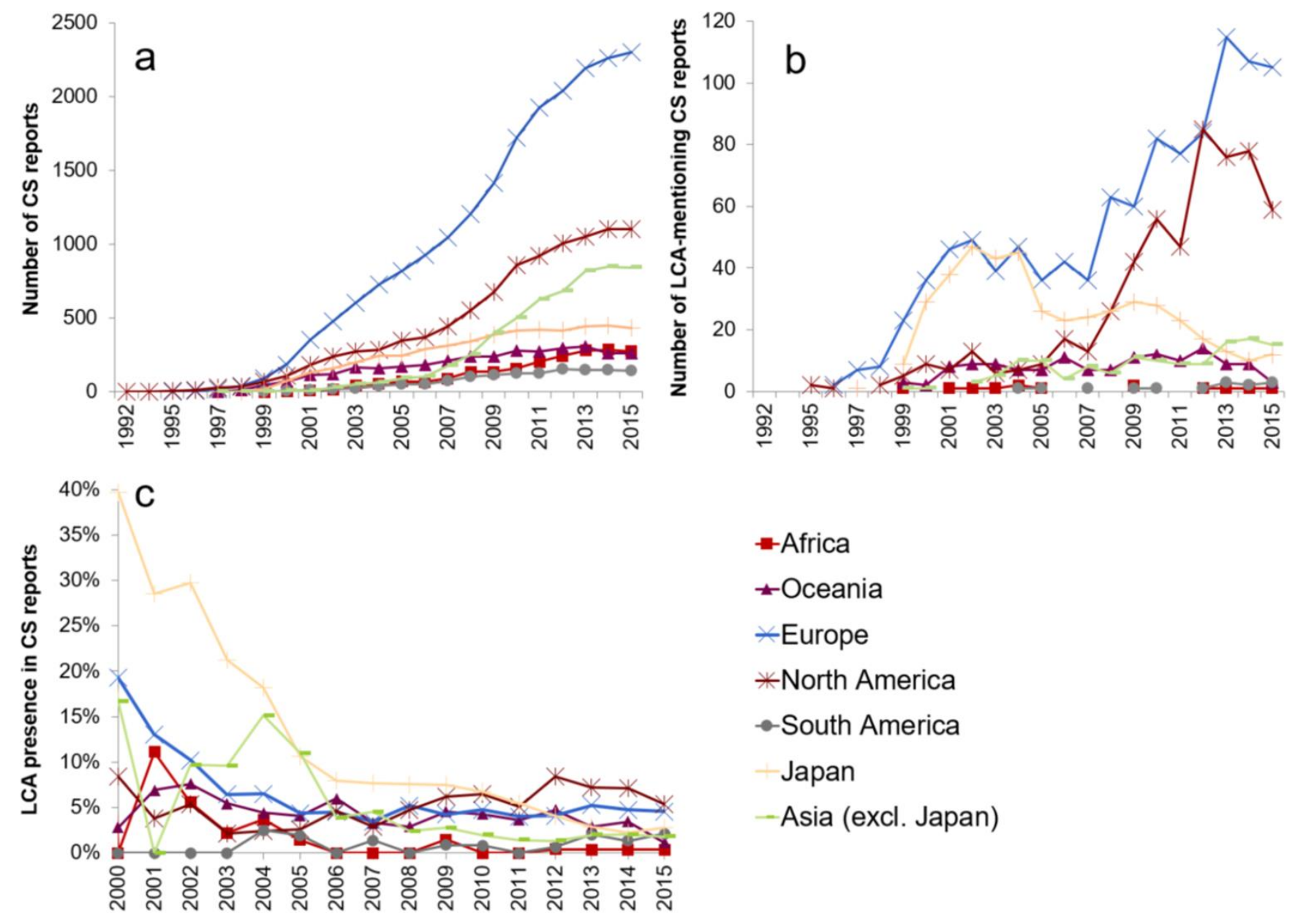

Figure 3. Temporal and regional evolutions in total number of CS reports (a), number of LCAmentioning CS reports (b) and LCA presence in CS reports (c). Japan was singled out because of its unique pattern within Asia. Note that in Figure 3c, the period 1995-1999 is not represented as it would show a series of spikes for all regions due to a very limited number of CS reports released in that period.

Figure 4 shows the LCA presence in CS reporting for the top 12 countries with the highest LCA presence aggregated over the period 1995-2015, i.e. the total number of CS reports referring to LCA in a given country relative to the total number of CS reports in that country over the whole period. High LCA presence in CS reporting is mostly observed in European countries, especially in the Nordic region. 


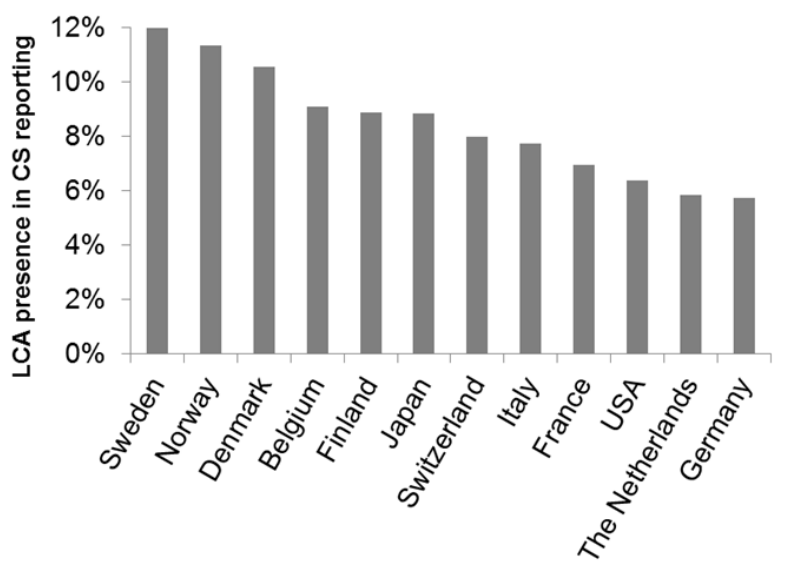

Figure 4. Top 12 countries with highest LCA presence in CS reporting aggregated over the period 1995-2015, i.e. the total number of CS reports referring to LCA in a given country relative to the total number of CS reports in that country over the whole period. A cut-off criterion of $500 \mathrm{CS}$ reports per country and cumulated over the time period was applied to prevent possible biases caused by countries with high LCA presence in CS reporting on a limited number of total CS reports.

\subsection{Sectoral trends}

\subsubsection{Sectoral differences of LCA presence in CS reports}

As illustrated in Figure 5, the mapping of LCA presence in CS reporting at a sector-level shows the same temporal trends as observed in Figure 2, with LCA presence in CS reporting ranging higher than $50 \%$ for a number of sectors (e.g. Containers \& Packaging, Industrial Machinery) in the late 1990s (Figure 5a), before decreasing in the early 2000s (maximum presence of ca. 20-25\%; Figure 5b) and somewhat stabilizing in the 2006-2015 period with average LCA presence of ca. $5 \%$ (Figure $5 \mathrm{c}$ and 5d). Apart from the period 2001-2005, no sector presents both a high number of CS reports and a high presence of LCA, which means that large sectors, in terms of released CS reports, contain relatively few occurrences of LCA. This is for example the case for the finance sector.

Over the considered 20 year-period, the Containers \& Packaging sector shows a systematically high LCA presence in CS reporting (above 18\% in all periods; see Figure 5). In the last considered period of 2011-2015, it stands out with an LCA presence as high as $25 \%$. The second highest LCA presence in 2011-2015 is observed for the Personal \& Household Goods sector, which is associated with an increasing presence of LCA in CS reporting over the past 20 years. Further analysis of sectoral trends (See Table S3 in Supplementary Results) reveals a stable or increasing LCA presence in the Chemicals, Industrial Metals, and Forestry \& Papers sectors, whereas other sectors have experienced a decreasing trend in recent periods, e.g. Electronic \& Electrical, Automobiles \& Parts, Diversified Industrials, Industrial Machinery, and Technology \& Hardware Equipment. 

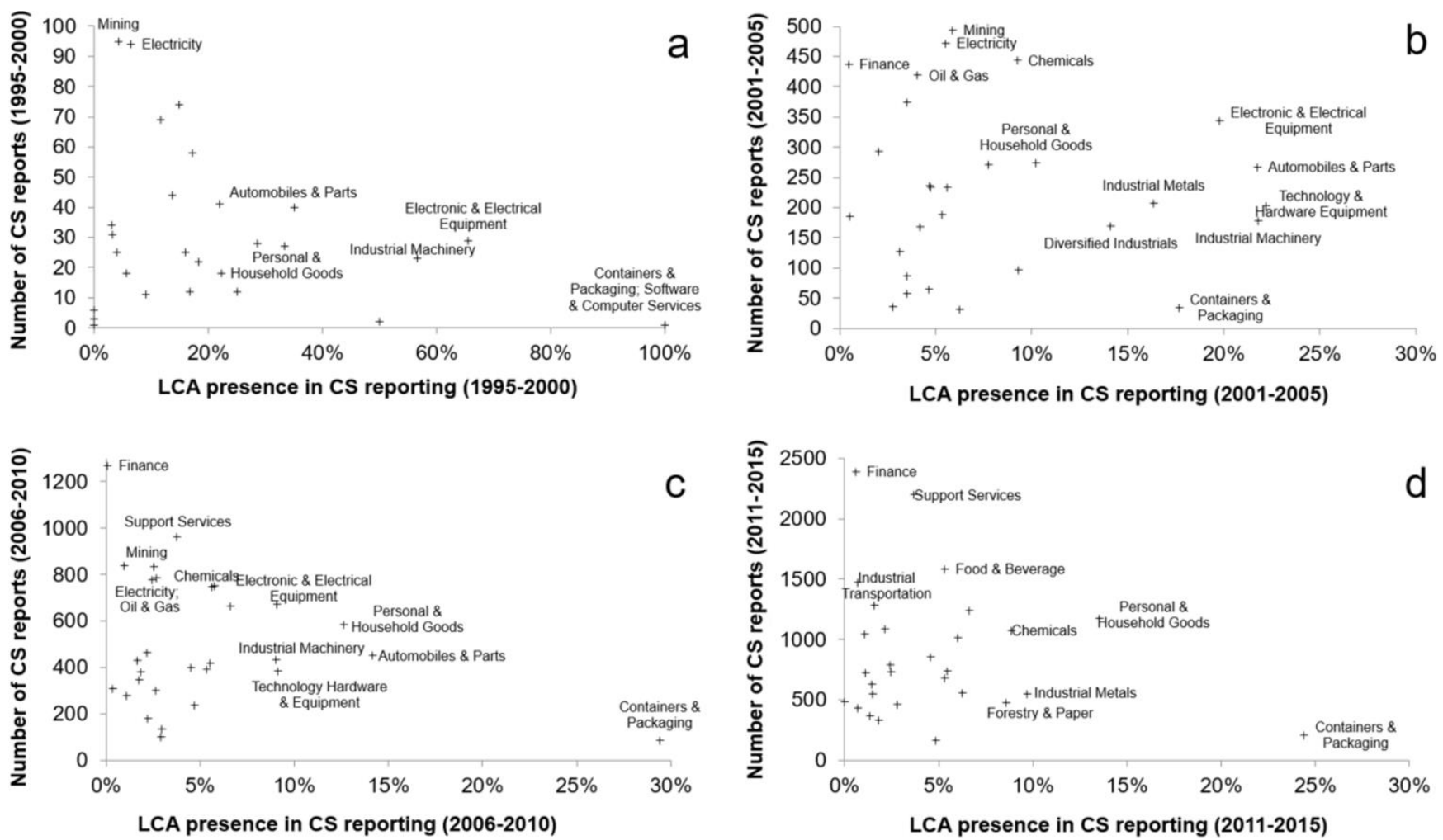

Figure 5. Sectoral LCA presence in CS reports and number of CS reports per sector in 1995-2000 (a); 2001-2005 (b); 2006-2010 (c); and 2011-2015 (d). Only largest sectors (top part of Figure 5) and sectors with highest LCA presence in CS reporting (right part of Figure 5) are labelled on Figure 5 to allow readability. All sectoral LCA presences in CS reporting are available in Table S3 in Supplementary Results. Note the different scales on the x-axis for the LCA presence as well as on the $y$-axis for all figures.

\subsubsection{Comparative analysis of sector types}

The business activity type was found to influence the presence of references to LCA in CS reports, with CS reports in manufacturing sectors showing higher presence of LCA than CS reports in the service sectors. This influence was statistically significant for both B2B and B2C subsets ( $p$-values < $\left.2.2^{*} 10^{-16}\right)$. In contrast, the influence of customer type was less apparent. The type of customer (business or consumer) was found independent from the presence of references to LCA in CS reports for the service-oriented sector subset $(p=0.35)$, but there was some dependency on the type of customer for the manufacturing sector subset $\left(p=7.2^{*} 10^{-8}\right)$, with B2C manufacturing companies showing slightly higher presence of LCA in CS reports than B2B manufacturing companies.

Subsequent analyses carried out for data separated further into subsets corresponding to the four periods of publications of CS reports, namely 1995-2000, 2001-2005, 2006-2010 and 2011-2015, showed that this dependency was only significant in the two latter periods 2006-2010 and 2011-2015 $\left(p=1.7^{*} 10^{-10}\right.$ and $4^{*} 10^{-4}$, respectively), but not in the first two ones ( $p=0.10$ and 0.39 , respectively). This apparent recent influence of the customer type mirrors the results at sector level showing that LCA 
presence in CS reports has diminished in some B2B manufacturing sectors (e.g. Electronic \& Electrical, Diversified Industrials, Industrial Machinery and Technology \& Hardware Equipment sectors), while remaining strong in the Personal \& Household Goods sector (B2C manufacturing sector) in the past years.

\subsubsection{Contribution of supply chain to total impacts}

Figure 6 shows the observed sectoral LCA presence in CS reporting for the period 2011-2015 in parallel to the proportion of indirect environmental impacts for each sector. Direct environmental impacts include the impacts generated by the companies' operations, while indirect environmental impacts are impacts lying in the supply chain. Estimated shares of indirect environmental impacts were retrieved from the study by GreenBiz and Trucost (2015). There seems to be no correlation between LCA presence in CS reports and the share of indirect environmental impacts. Especially, several sectors for which the impact contribution from supply chains is high $(>75 \%)$ have very low LCA presence in CS reporting, for example the Finance, Software \& Computer Service,

Telecommunications, Media, Retail, Health Care Equipment \& Services and Real Estate sectors.

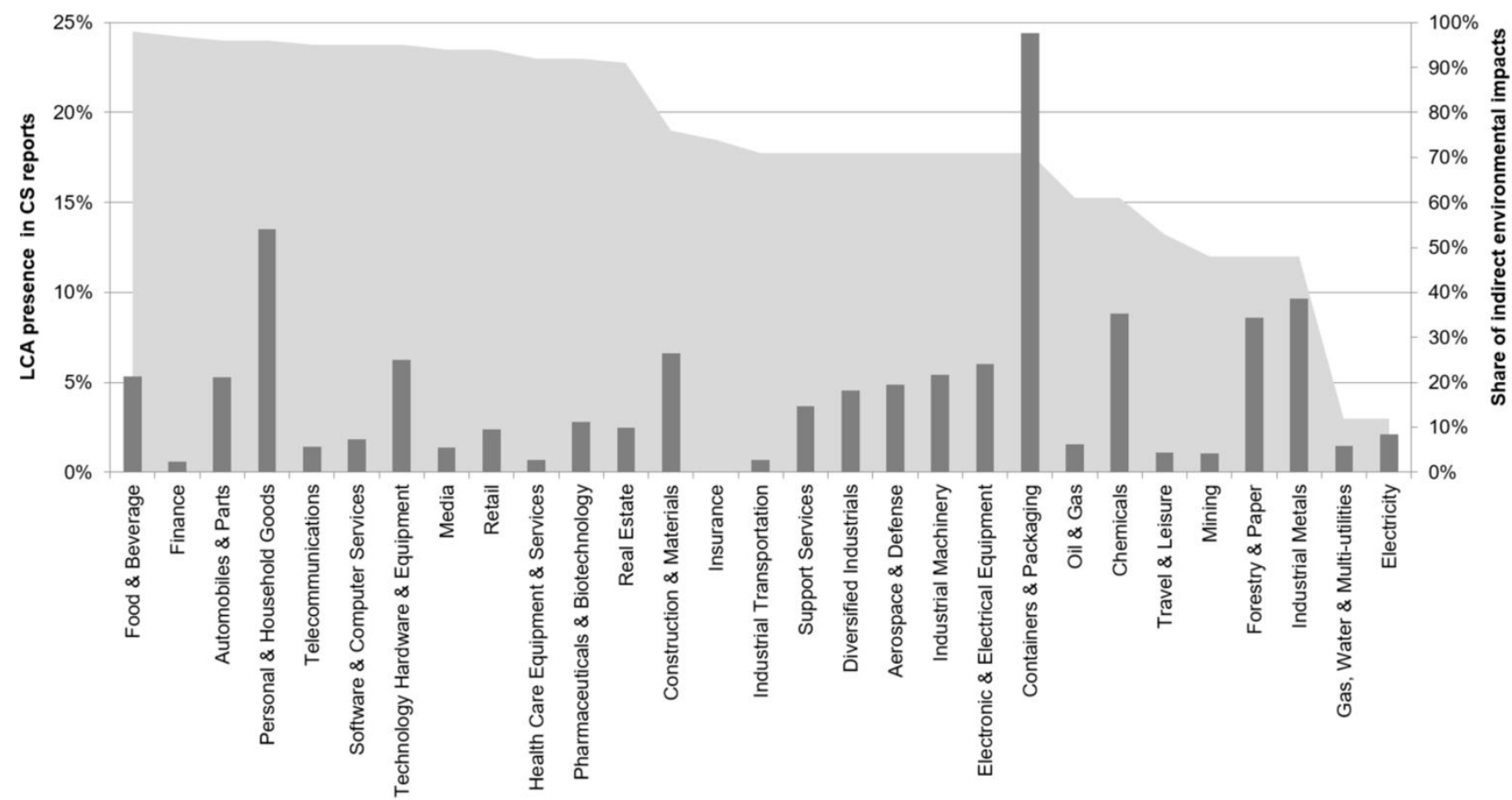

Figure 6. LCA presence in CS reporting (dark grey bars; left y-axis) opposed to the share of indirect environmental impact (light grey area; right y-axis) per sector over the period 2011-2015. Estimated shares of indirect environmental impacts were adapted from GreenBiz and Trucost (2015). The correspondence between the sectors used by GreenBiz and Trucost and the sectors used in this study is available in Table S1. 


\subsection{Company-level trends}

As shown in Figure 7, amongst the total of 1167 companies referring to LCA during the 1995-2015 period, more than $75 \%$ of companies had made references in just 1 or 2 of the years. This clearly shows that very few companies mention LCA in their CS reports on a regular basis. Only $12 \%$ of the companies have referred to LCA in four or more years and only $1 \%$ in eight or more years in the 19952015 period (not visible in Figure 7).

However, it should be noted that not all companies release CS reports every year. Consequently, the observed discontinuities in LCA-mentioning reports may be due to either a discontinuity in the CS reporting or a discontinuity in the reference to LCA in CS reports. The analysis of the data shows that only $35 \%$ of all discontinuities of LCA references are due to discontinuities in CS reporting activities at the company (data not shown). Thus, there are large changes in the references to LCA in CS reports between years, regardless of the companies' CS reporting frequency.

Data show that the companies, which mentioned LCA in their CS reports at least once in the period 1995-2000 (111 companies), have mentioned LCA on average in three distinct years, in the period 1995-2015 (data not shown). In this group of companies, discontinuities in the presence of LCA in CS reports are explained by discontinuities in CS reporting activities in $31 \%$ of cases. Hence, early references to LCA in CS reports are not associated with continuous references to LCA over the full time period.

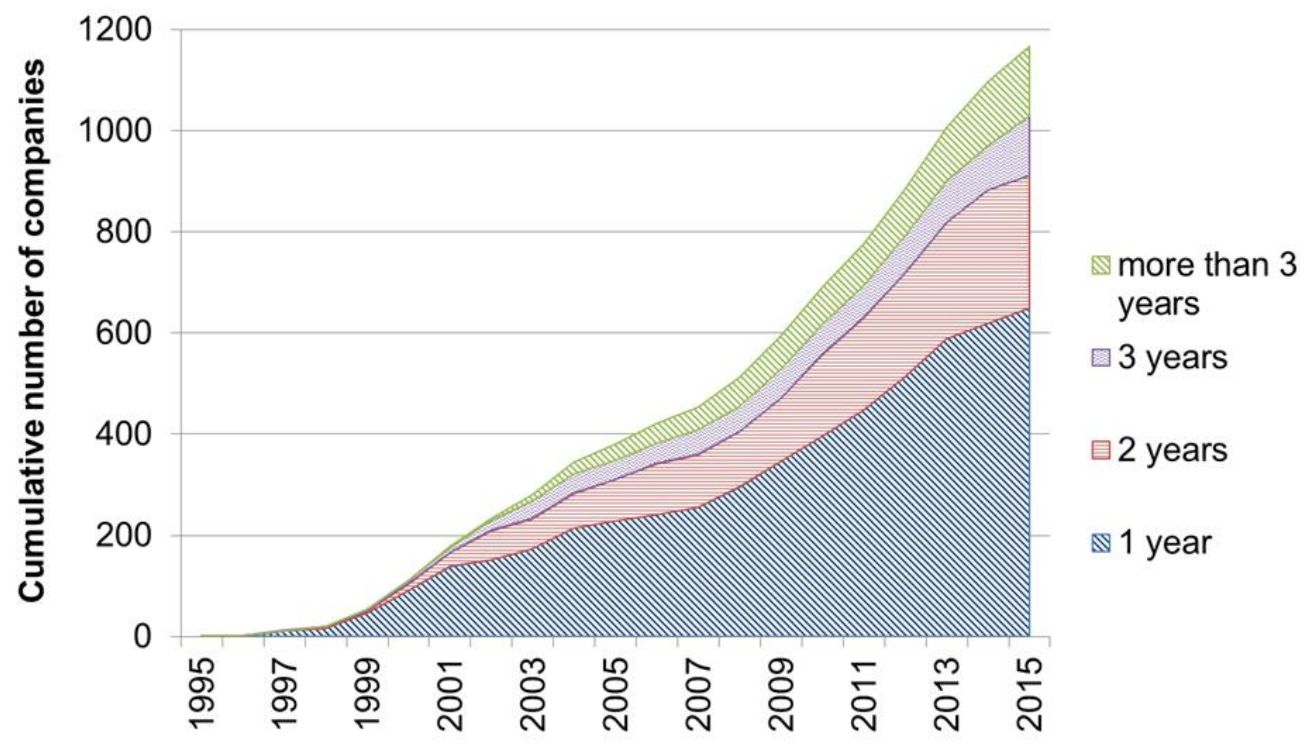

Figure 7. Cumulative number of companies having mentioned LCA in their CS reports before or at the indicated year. 


\section{Discussion}

\subsection{Analysis of trends}

The observed temporal, regional and sectoral trends can be put in perspective by the developments of the LCA methodology and initiatives undertaken to drive its uptake by industry; yet the existence of causality in observed relationships should be regarded with care. The first instances of LCA in CS reports stem from approximately five years after the kick-off of the development of a life cycle impact assessment (LCIA) framework for LCA by SETAC (SETAC, 1991).

At a geographical level, the areas where LCA networks (Bjørn et al, 2013) and academic publications (De Souza and Barbastefano, 2011) have been reported to be the strongest, namely in Europe and North America, match the areas where the highest levels of LCA presence in CS reporting are observed. The contrasting low presence of LCA networks and LCA-related academic activities reported for Africa and South America are also consistent with the low LCA presence in CS reporting observed in these regions (Bjørn et al., 2013; De Souza and Barbastefano, 2011). However, the regional variation of LCA presence in CS reporting remains small, and regions where LCA is promoted strongly do not show much stronger LCA presence in CS reporting than regions where LCA promotion is weak. Such observations must be nuanced with the relative sizes of the involved regions in terms of CS reports, considering that North America and Europe have about five times more CS reports than Africa and South America over the whole period. The strong representation of Nordic countries among countries with high LCA presence in CS reporting is consistent with the strong uptake of LCA in the Nordic region, with respect to LCA application and method development (Hanssen, 1999; Bjørn et al., 2013; Laurent et al., 2014).

The two sectors with highest LCA presence, namely Containers \& Packaging and Personal \& Household Goods, were documented as sectors of early application of LCA in the literature (Gloria et al, 1995; Berkhout, 1996; Hanssen, 1999; Hauschild et al, 2005). The EU directive on packaging and packaging waste promoted the use of a life cycle approach to compare different types of packaging (EC, 1994). The sectors Personal \& Household Goods, Chemicals, and Forestry \& Papers demonstrate a coincidence between high LCA presence in CS reports and product categories with highest numbers of eco-labelled products, such as paints and varnishes, tissues, copy and graphic paper, cleaning products, textiles, and rinse-off cosmetics (EC, 2018c). The relatively high LCA presence in CS reports in the Industrial Metal, Forestry \& Papers and Chemical sectors also seem to coincide with initiatives for promoting and harmonizing the application of the LCA methodology in these industrial sectors (PWC and FPAC, 2010; WBCSD Chemical, 2014; PE International, 2014; Santero and Hendry, 2016).

A comparison of the LCA presence levels in CS reporting and the development of EPD for different sectors shows correlations of varying strengths. EPDs have recently been promoted in the building sector by the EU regulation No 305/2011 (EC, 2011; Ibanez-Forés et al., 2016) and this sector has shown a net increase of issued EPDs (Ibanez-Fores et al., 2016). This is reflected to some extent in the current study since the Construction \& Materials sector presents a LCA presence of approximately $7 \%$ in CS reporting for the past 5 years, hence slightly higher than the average (see Table S3 in 
Supplementary Results). The sector Food \& Agricultural products is also an area where EPDs have recently become very popular (Ibanez-Fores et al., 2016), but in our study, the Food \& Beverage sector only shows average LCA presence in CS reports (5.3\%) for the period 2011-2015.

The differences observed between service and manufacturing sectors echo studies that reported a low utilization of LCA in the service sector (Graedel, 1997; Baumann, 1996; Sousa and Ometto, 2011). More recently in a survey of 800 large European companies, Chiarini (2014) found equal recognition of the value of the LCA methodology to support purchasing practices among service and manufacturing companies. Yet, such balance is not reflected in our findings, where service companies were found to refer considerably less to LCA than manufacturing companies, even in the most recent period ( $7 \%$ for manufacturing sector and $2 \%$ for service sector - see Table S4). The relatively low LCA presence in CS reports of sectors with high environmental impacts in their supply chains is consistent with findings from the Carbon Disclosure Project (CDP, 2016), which revealed that Scope 3 greenhouse gas emissions are underreported, notably for sectors associated with high indirect emissions. Unlike Scope 1 and 2 emissions, Scope 3 emissions can only be assessed by adopting a life cycle perspective (GHG Protocol, 2011).

\subsection{Challenges and opportunities for LCA presence in CS reporting}

Overall, the mapping revealed a rather weak presence of LCA in CS reports (around $5 \%$ in the most recent period) and large variations in company reporting over years. Hence, in spite of initiatives from industry associations and policy-makers promoting the use of LCA in industry, companies are rarely referring to LCA in their CS narratives.

This relative absence of LCA in CS reports may reflect that the companies do not work with LCA. Earlier studies have indeed indicated that LCA could be regarded as too costly, too complex or unreliable (Schaltegger, 1997; Cooper and Fava, 2006). It may also be related to a decision not to communicate about LCA, possibly because the topic is regarded as of low importance by the reporting company, is weakly advocated in CS reporting guidelines or is not requested by stakeholders (Searcy and Buslovich, 2014). GRI 4 reporting guidelines suggest the use of LCA as a tool to identify material issues, "which reflect the organization's significant economic, environmental and social impacts"; or "substantively influence the assessments and decisions of stakeholders" (GRI, 2013), and to document energy requirements of products or services throughout their life cycle. Yet the LCA methodology is not emphasized further in the guidelines. The company-level mapping further revealed that companies who mention the LCA methodology do not do so continuously over time, thus indicating either a discontinuity in LCA activities at the company or a reprioritization towards other or new sustainability practices in CS reports, with the LCA methodology being removed because CS reports need to remain short enough (Searcy and Buslovich, 2014). Since the company may well continue LCA practices without reporting it, such findings indicate that LCA presence in CS reports may not be a good proxy for LCA utilization at the company.

The low LCA presence may also be explained by the fact that some LCA results are unfavorable to the business activities (Berkhout, 1996), not peer reviewed (Jensen et al., 1997) or deemed unsuited for the audience (Goedkoop et al., 2015; Testa et al., 2016). Omitting references to LCA in CS 
reporting due to unfavorable results could be motivated by the company's use of CS reporting to legitimize its business and manage its sustainability reputation (Hooghiemstra, 2000; Hahn and Kühnen, 2013). Single life-cycle impact indicators, like carbon footprint or water footprint, may also be preferred over more complex LCA results because they are simpler to communicate (Weidema et al., 2008; Molina-Murillo and Smith, 2009). Harmonized guidance on how to conduct LCA of specific products, as offered by the PEF guidelines in the EU (EC, 2018a), is an opportunity to facilitate the communication of product life cycle information by companies and may contribute to more referring to product LCA in CS reports.

The diversification of sustainability disclosures in CS reports, i.e. from a sole focus on environmental issues to a broad variety of sustainability aspects, may have caused LCA to drop in the CS reporting agenda in the period 1999-2007 because of its strong focus on the environment (Kolk, 2003; Hahn and Kühnen, 2013; Siew, 2015). In this perspective, life cycle methodologies allowing a broader coverage of sustainability aspects, such as life cycle sustainability assessment (including environmental life cycle assessment, social life cycle assessment and life cycle costing), could be beneficial (Finkbeiner et al., 2010). A check in the CS reports database revealed that references to social LCA, life cycle costing and life cycle sustainability assessment were nearly absent in the pool of CS reports (data not shown). These methodologies have not yet reached the same level of maturity as environmental LCA, and method developments and consensus efforts are still required for their consistent application (Finkbeiner et al., 2010; Zamagni, 2012; Guinée, 2016).

Although organization and product-level information coexist in CS reports, we have highlighted in Section 2.2 that organization-level disclosures dominate in the GRI reporting guidelines. In this perspective, developments of the LCA methodology for application to an organizational scope, including the UNEP guidance document (UNEP, 2015), the ISO 14072 standard (ISO, 2014) and the EU general and sectoral guidance documents for OEF (EC, 2016; 2018b) may play a key role in strengthening LCA application in CS reporting. Organizational LCA may suit the reporting needs of companies with large product portfolios better, although the increased complexity associated with tracking a large number of products and product families has also been highlighted (Martínez-Blanco et al., 2016). Quantitative indicators used in current CS reporting have in earlier studies been found to cover only part of the life cycle of corporate activities and to be defined at a flow-level rather than at an environmental impact level, e.g. in terms of waste, energy or material flows (Pflieger et al., 2005; Kaenzig et al., 2014). Hence, integrating organizational LCA in CS reports would require an important shift from current corporate environmental assessment practices.

Masanet and Chang (2014) who conducted a survey on 900 prospective users of LCA located in North America and mainly working in the private sector found that more than $60 \%$ had the intention to apply LCA in their professional decisions and around 35\% indicated that they intended to apply LCA in corporate environmental reporting. Although such engagement cannot be observed in our results, future evolutions of the presence of LCA in CS reports seem worth tracking. 


\subsection{Recommendations for strengthening the presence of LCA in CS reporting}

LCA methodology developers and proponents of its use by industry can play a key role in strengthening the presence of LCA in CS narratives by (i) providing detailed guidelines for presenting LCA activities in CS reports, (ii) expanding its utilization to the organizational scope, i.e. through organizational LCA, and (iii) understanding and addressing the reasons behind a lower presence of the LCA methodology in CS reporting of service sectors.

In order to broaden the use of the LCA methodology in CS reports, adjustments in existing reporting guidelines and requirements from policy-makers would also create meaningful drivers. The recognition of LCA as an indication of sustainability management practice in industry among investors or evaluation approaches of external ranking agencies could facilitate a wider use and dissemination of LCA. Hence, more emphasis should be put on the LCA methodology in external evaluation approaches of CS reporting. For example, in the EU, the sustainable finance action plan launched in 2018 requires companies to strengthen their non-financial information disclosures. A strong life cycle focus could be anchored in such initiatives to complement the current focus on applicability of the EU eco-label framework for financial products (EC, 2018d).

Finally, companies are generally recommended to explore the possible inclusion of the LCA methodology to document their environmental sustainability efforts in CS reporting, especially within service sectors, where the LCA presence in CS reports is low, albeit relevant owing to their high known environmental impacts through their supply chains (Rosenblum et al., 2000). Moreover, companies should be encouraged to make explicit reference to the LCA methodology in order to ensure terminology alignment and allow readers to put specific company practices into a broader perspective by benchmarking them against industry practices.

\subsection{Limitations of the study}

Due to limitations in the database used and associated search function, only CS reports - and not the companies - could be considered as units of analysis for the calculations of LCA presence in CS reports. Some companies release several CS reports per year, while others release biannual CS reports. The use of CS reports as unit of analysis therefore introduces biases between the sectors, regions or countries, in which many companies release several reports per year and mention LCA in all of them, and those in which many companies release several reports per year but do not mention LCA. However, in our study, the results are intended to show the overall presence of LCA in CS reporting across sectors, regions and countries at large, and we therefore consider it appropriate to use CS reports as a unit of analysis.

The focus on CS reports written in English specifically led to discarding companies only publishing in their national language, thus introducing a potential bias for non-English-speaking regions. For example, searches in the Corporate Register database showed that only $30 \%$ and $52 \%$ of all CS reports included in the database and released by companies with respectively headquarters in Spain and France were written in English. Similarly, the Corporate Register database contains a limited 
number of CS reports from Chinese companies (518 released in 1992-2015) although other academic studies report higher numbers of reports published by Chinese companies (Wang et al., 2017).

The present mapping relies on the identification of references to the LCA methodology in CS reports. However, the terminology used by companies to communicate about LCA is not harmonized and companies may mention LCA-related terms for assessments that only cover climate-related impacts, while others will refer to such assessments as "carbon footprints". They may alternatively have developed tailored indicators strongly based on the LCA methodology and refer to them in their CS reports with no explicit reference to the LCA methodology, hence not captured in the mapping. This lack of terminology alignment may have generated some discrepancies in the identified CS reports mentioning LCA.

Furthermore, some difficulties were experienced in filtering LCA-mentioning CS reports using the content search tool available from the Corporate Register database. A number of reports could be identified as mentioning LCA-related terms while not appearing in the search results, thus leading to possible underestimations in the number of identified LCA-mentioning CS reports. Given the large number of retrieved CS reports (>2300), this limitation is not expected to impact the observations and analyses performed in this study. Yet, caution should be exerted when addressing specific regions or sectors with very few listed CS reports, as these are more likely to be significantly influenced (due to low number of data points).

CS reports are a communication tool for companies, and earlier academic studies have shown that companies may use them to shape their corporate reputation and image, without reporting substantial activities to tackle their sustainability challenges (Deegan and Rankin, 1996; Hooghiemstra, 2000; Hrasky, 2011; Talbot and Boiral, 2018). In this perspective, the context around LCA references in CS reports needs critical analysis, although it was considered outside the scope of the present paper. In particular, future studies could focus on exploring the purpose and actual use of LCA as narrated in CS reports.

\section{Conclusions and outlook}

The present study constitutes a first attempt to analyze the presence of the LCA methodology in companies' narratives of their sustainability efforts in CS reporting. The results show that: (i) the absolute number of LCA-mentioning CS reports has greatly increased over time, (ii) LCA presence (relative occurrence) in CS reports has decreased over time and now stabilized around 5\%; (iii) there are geographical and sectoral variations, and LCA presence is weak in CS reports of service companies; (iv) LCA presence in CS reports is variable across years at the level of individual companies. The visibility of the LCA methodology in CS reports, and hence in companies' narratives of their sustainability efforts, needs strengthening, considering the recognition of the LCA methodology to guide sustainability efforts at companies. In this perspective, guidelines on how to document the application of the LCA methodology in CS reports, as well as a stronger focus on the LCA methodology in CS reporting guidelines, requirements from policy-makers, and expectations from investors and ranking agencies seem particularly needed. 
To take this first study further, avenues for future research can be framed and prioritized according to three main directions. First, the relatively descriptive approach undertaken in the current study should be complemented by future statistical analysis testing the influence that additional factors, such as the use of reporting guidelines or the position of the company in the value chain, exert on the LCA presence in CS reports. Second, there is a need to survey companies about their motivations or lack thereof to refer to LCA in CS reporting, and to better understand the impact that various initiatives promoting LCA adoption in industry may have on reporting practices. Third, the specific references to LCA in CS reports need deeper investigation through reviews of the reports to see what information companies actually report with regard to LCA. This latter point will be addressed in a sequel paper (Stewart et al., in preparation).

\section{Acknowledgements}

P. F. acknowledges the financial support of the Marie Curie project Quan-Tox (grant agreement no. 631910) funded by the European Commission under the Seventh Framework Programme.

\section{References}

American Center for Life Cycle Assessment. 2017. About ACLCA. http://www. http://aclca.org/about/ [7 February 2018]

Baumann, H. 1996. LCA use in Swedish industry. International Journal of Life Cycle Assessment 1(3): 122-126. DOI: 10.1007/BF02978937

Berkhout, F. 1996. Life Cycle Assessment and Innovation in Large Firms. Business Strategy and the Environment 5(3): 145-155. DOI: 10.1002/(SICI)1099-0836(199609)5:3<145::AIDBSE65>3.0.CO;2-P

Berkhout, F, Howes, R. 1997. The adoption of life-cycle approaches by industry: Patterns and impacts. Resources, Conservation and Recycling 20: 71-94. DOI: 10.1016/S09213449(97)01199-3

Bjørn, A, Owsianiak, M, Laurent, A, Molin, C, Westh, TB and Hauschild, MZ. (2013) Mapping and characterization of LCA networks. International Journal of Life Cycle Assessment, 18(4): 812827. DOI: 10.1007/s11367-012-0524-6

Bjørn, A, Bey, N, Georg, S, Røpke, I, Hauschild, MZ. 2017. Is Earth recognized as a finite system in corporate responsibility reporting? Journal of Cleaner Production 163: 106-117. DOI:10.1016/j.jclepro.2015.12.095

Bjørn, A, Owsianiak, M, Molin, C, Hauschild, MZ. 2018. LCA History. In Life Cycle Assessment. Theory and Practice, Hauschild, MZ, Rosenbaum, R, Olsen, SI (eds). Springer International Publishing: Cham. DOI: 10.1007/978-3-319-56475-3

Borga, F, Citterio, A, Noci, G, Pizzurno, E. 2009. Sustainability report in small enterprises: Case studies in Italian furniture companies. Business Strategy and the Environment 18(3): 162-176. DOI:10.1002/bse.561

Carbon Disclosure Project (CDP). 2016. Out of the starting blocks Tracking progress on corporate 
climate action.

Chen, H, Yang, Y, Yang, Y, Jiang, W, Zhou, J. 2014. A bibliometric investigation of life cycle assessment research in the web of science databases. International Journal of Life Cycle Assessment 19(10): 1674-1685. DOI: 10.1007/s11367-014-0777-3

Chiarini, A. 2014. Strategies for developing an environmentally sustainable supply chain: Differences between manufacturing and service sectors. Business Strategy and the Environment 23(7): 493504. DOI: 10.1002/bse.1799

Comas Martí, JM, Seifert, RW. 2013. Assessing the comprehensiveness of supply chain environmental strategies. Business Strategy and the Environment 22(5): 339-356.

DOI:10.1002/bse. 1749

Cooper, JS, Fava, JA. 2006. Life-Cycle Assessment Practitioner Survey: Summary of Results. Journal of Industrial Ecology 10(4): 12-14. DOI: 10.1162/jiec.2006.10.4.12

CR, 2017a, Corporate Register. http://www.corporateregister.com [7 February 2017].

CR, 2017b. About Reports. http://www.corporateregister.com/aboutreports.html [7 February 2017].

Dyllick, T, Rost, Z. 2017. Towards true product sustainability. Journal of Cleaner Production 162(): 346-360. DOI: 10.1016/j.jclepro.2017.05.189.

EC. 1994. European Parliament and Council Directive 94/62/EC of 20 December 1994 on packaging and packaging waste. Off J Eur Union 365.

EC. 2003. Communication from the Commission to the Council and the European Parliament Integrated Product Policy - Building on Environmental Life-Cycle Thinking. http://eurlex.europa.eu/legal-content/EN/ALL/?uri=CELEX:52003DC0302 [7 February 2018]

EC. 2009. Directive 2009/125/EC of the European Parliament and of the Council of 21 October 2009 establishing a framework for the setting of ecodesign requirements for energy-related products. Off J Eur Union 285:10-35 http://data.europa.eu/eli/dir/2009/125/oj [7 February 2018]

EC. 2010. Regulation No 66/2010 of the European Parliament and of the Council of 25 November 2009 on the EU Ecolabel.

EC. 2011. Regulation (EU) No 305/2011 of the European Parliament and of the Council of 9 March 2011 laying down harmonized conditions for the marketing of construction products and repealing Council Directive 89/106/EEC. Off J Eur Union 88:5-43 http://data.europa.eu/eli/reg/2011/305/oj [7 February 2018]

EC. 2014. Directive 2014/95/EU of the European Parliament and of the Council of 22 October 2014 amending Directive 2013/34/EU as regards disclosure of non-financial and diversity information by certain large undertakings and groups. Off J Eur Union 330:1-9 http://data.europa.eu/eli/dir/2014/95/oj

EC. 2015. Better Regulation Guidelines. Commission staff working document. COM(2015) 215 final; SWD(2015) 111 final. May 2015. EU Commission. Strasbourg, France. http://ec.europa.eu/smartregulation/guidelines/docs/swd_br_guidelines_en.pdf [05 April 2017]. 
EC. 2016. Guidance for the implementation of the EU Organisation Environmental Footprint (OEF) during the Environmental Footprint (EF) Pilot Phase. Version 4.0. http://ec.europa.eu/environment/eussd/smgp/pdf/Guidance organisations.pdf [26 July 2018]

EC. 2018a. PEFCR Guidance document, - Guidance for the 14 development of Product Environmental Footprint Category Rules (PEFCRs).

http://ec.europa.eu/environment/eussd/smgp/pdf/PEFCR_guidance_v6.3.pdf [26 July 2018]

EC. 2018b. Organisation Environmental Footprint 1 Sector Rules Guidance. Version 6.3, May 2018. European Commission, Brussels, BE. http://ec.europa.eu/environment/eussd/smgp/PEFCR OEFSR en.htm [14 July 2018]

EC. 2018c. Ecolabel. Facts and Figures. http://ec.europa.eu/environment/ecolabel/facts-andfigures.html [20 July 2018].

EC. 2018d. Communication from the Commission to the European Parliament, the European council, the council, the European Central Bank, the European Economic and Social Committee and the Committee of the Regions. Action Plan: Financing Sustainable Growth. https://eurlex.europa.eu/legal-content/EN/TXT/PDF/?uri=CELEX:52018DC0097\&from=EN [19 July 2018]

Ernst and Young. 2014. Sustainability Reporting. The time is now. https://www.ey.com/Publication/vwLUAssets/EY-Sustainability-reporting-the-time-isnow/\$FILE/EY-Sustainability-reporting-the-time-is-now.pdf. [19 July 2018]

EU-JRC. 2010. Making sustainable consumption and production a reality. A guide for business and policy makers on Life Cycle Thinking and Assessment. European Union. DOI: 10.2779/91521.

Deegan, C, Rankin, M. 1996. Do Australian companies report environmental news objectively?: An analysis of environmental disclosures by firms prosecuted successfully by the Environmental Protection Authority. Accounting, Auditing \& Accountability Journal 9(2): 50-67. DOI: 10.1108/09513579610116358

Finkbeiner, M, Schau, EM, Lehmann, A, Traverso, M. 2010. Towards life cycle sustainability assessment. Sustainability 2:3309-3322. DOI: 10.3390/su2103309

Finkbeiner, M. 2016. Introducing "Special Types of Life Cycle Assessment". In LCA Compendium The Complete World of Life Cycle Assessment. Special Types of Life Cycle Assessments, Finkbeiner, M (ed). Springer Netherlands: Dordrecht. DOI: 10.1007/978-94-017-7610-3

Finnveden, G, Hauschild, MZ, Ekvall, T, Guinée, J, Heijungs, R, Hellweg, S, Koehler, A, Pennington, D, Sangwon, S. 2009. Recent developments in Life Cycle Assessment. Journal of Environmental Management 91:1-21. DOI: 10.1016/j.jenvman.2009.06.018.

Frankl, P, Rubik, F. 2000. Life Cycle Assessment in Industry and Business. Adoption Patterns, Applications and Implications. Springer-Verlag Berlin Heidelberg: New York. DOI: 10.1007/978-3662-04127-7

GHG Protocol. 2011. Corporate Value Chain (Scope 3) Accounting and Reporting Standard. Supplement to the GHG Protocol Corporate Accounting and Reporting Standard. https://ghgprotocol.org/standards/scope-3-standard [26 July 2018] 
Guinée, J. 2016. Life Cycle Sustainability Assessment: What Is It and What Are Its Challenges? In Taking Stock of Industrial Ecology, Clift, R, Druckman, A (eds). Springer: Cham. DOI: 10.1007/978-3-319-20571-7

Global Reporting Initiative (GRI). 2013. G4 Sustainability Reporting Guidelines. Implementation Manual. https://www.globalreporting.org/resourcelibrary/GRIG4-Part2-ImplementationManual.pdf. [7 February 2018]

Gloria, T, Saad, T, Breville, M, O'Connell, M. 1995. Life Cycle Assessment: A Survey of Current Implementation. Total Quality Environmental Management 4(3): 33-50. DOI: 10.1002/tqem.3310040306

Goedkoop, M, Mieras, E, Gaasbeek, A, Contreras, S. 2015. How to Make the Life Cycle Assessment Team a Business Partner. In LCA Compendium - The Complete World of Life Cycle Assessment. Life Cycle Management, Sonnemann, G, Margni, M. (eds). Springer Netherlands. DOI: 10.1007/978-94-017-7221-1

Graedel, T.E. 1997. Life-Cycle Assessment in the Service Industries. Journal of Industrial Ecology 1(4): 57-70. DOI: $10.1162 / \mathrm{jiec} .1997 .1 .4 .57$

GreenBiz and Trucost. 2015. State of Green Business 2015. https://www.greenbiz.com/report/stategreen-business-report-2015 [7 February 2018]

Gold, S, Heikkurinen, P. 2018. Transparency fallacy: Unintended consequences of stakeholder claims on responsibility in supply chains. Accounting, Auditing \& Accountability Journal 31(1): 318-337. DOI: 10.1108/AAAJ-06-2015-2088

Hahn, R, Kühnen, M. 2013. Determinants of sustainability reporting: A review of results, trends, theory, and opportunities in an expanding field of research. Journal of Cleaner Production 59: 521. DOI:10.1016/j.jclepro.2013.07.005

Hanssen, OJ. 1999. Status of Life Cycle Assessment (LCA) activities in the Nordic Region. The International Journal of Life Cycle Assessment 4(6): 315-320. DOI: 10.1007/BF02978519

Hauschild, MZ, Jeswiet, J, Alting, L. 2005. From life cycle assessment to sustainable production: status and perspectives. CIRP Annals-Manufacturing Technology 54(2): 535-555. DOI: 10.1016/S0007-8506(07)60017-1

Hedberg, CJ, von Malmborg, F. 2003. The Global Reporting Initiative and corporate sustainability reporting in Swedish companies. Corporate Social Responsibility and Environmental Management 10:153-164. DOI: 10.1002/csr.38.

Hellweg, S, Milà i Canals, L. 2014. Emerging approaches, challenges and opportunities in life cycle assessment. Science 344 (6188): 1109-1113. DOI: 10.1126/science.1248361.

Herzig, C, Schaltegger, S. 2006. Corporate sustainability reporting: An overview. In Sustainability Accounting and Reporting, Schaltegger, S, Bennett, M, Buritt, R (eds). Springer Netherlands: Dordrecht. DOI: 10.1007/978-1-4020-4974-3

Hooghiemstra, R. 2000. Corporate Communication and Impression Management - New Perspectives Why Companies Engage in Corporate Social Reporting. Journal of Business Ethics 27(1): 55-68. 
DOI: 10.1023/A:1006400707757

Hrasky, S, 2011. Carbon footprints and legitimation strategies: symbolism or action? Accounting, Auditing \& Accountability Journal 25(1):174-198. DOI: 10.1108/09513571211191798

Hu, Q, Mao, G, Zhao, L, Du, H, Zuo, J. 2015. Mapping the scientific research on life cycle assessment: a bibliometric analysis. International Journal of Life Cycle Assessment 20(4): 541555. DOI: 10.1007/s11367-015-0846-2

Hörisch, J, Ortas, E, Schaltegger, S, Álvarez, I. 2015. Environmental effects of sustainability management tools: An empirical analysis of large companies. Ecological Economics 120: 241249. DOI: 10.1016/j.ecolecon.2015.11.002

Ibanez-Fores, V, Pacheco-Blanco, B, Capuz-Rizo, SF and Bovea, MD. 2016. Environmental Product Declarations: Exploring their evolution and the factors affecting their demand in Europe. Journal of Cleaner Production 116: 157-169. DOI: 10.1016/j.jclepro.2015.12.078

Industry Classification Benchmark. 2017. Industry Structure and Definitions. http://www.ftse.com/products/downloads/lCBStructureEng.pdf? ga=2.230737878.876067043.1513691036-1202434678.1513691036 [7 February 2018]

ISO. 2006. ISO 14044:2006. Environmental management—life cycle assessment—requirements and guidelines. International Organization for Standardization http://www.iso.org/iso/catalogue detail?csnumber=38498 [7 February 2018]

ISO. 2014. ISO/TS 14072: environmental management - life cycle assessment - requirements and guidelines for organizational life cycle assessment. International Organization for Standardization, Geneva.

Jensen, A, Hoffman, L, Møller, BT, Schmidt, A, Christiansen, K, Elkington, J, van Dijk, F. 1997. Life Cycle Assessment. A Guide to Approaches, Experiences and Information Sources, Environmental Issue Report No 6. https://www.eea.europa.eu/publications/GH-07-97-595-EN-C

Kaenzig, J, Friot, D, Saadé, M, Margni, M, Jolliet, O. 2011. Using Life Cycle Approaches to Enhance the Value of Corporate Environmental Disclosures. Business Strategy and the Environment 20(1): 38-54. DOI: 10.1002/bse.667

Kolk, A. 2003. Trends in sustainability reporting by the fortune global 250 . Business Strategy and the Environment 12: 279-291. DOI: 10.1002/bse.370

Kolk, A. 2010. Trajectories of sustainability reporting by MNCs. Journal of World Business 45(4): 367374. DOI: 10.1016/j.jwb.2009.08.001

Kozlowski, A, Searcy, C, Bardecki, M. 2015. Corporate sustainability reporting in the apparel industry: An analysis of indicators disclosed. International Journal of Productivity and Performance Management 64(3):377-397. DOI: 10.1108/IJPPM-10-2014-0152.

KPMG. 2015. Currents of Change. The KPMG Survey of Corporate Responsibility Reporting 2015. https://assets.kpmg.com/content/dam/kpmg/pdf/2016/02/kpmg-international-survey-of-corporateresponsibility-reporting-2015.pdf. [7 February 2018] 
Landrum, NE, Ohsowski, B. 2017. Identifying Worldviews on Corporate Sustainability: A Content Analysis of Corporate Sustainability Reports. Business Strategy and the Environment 27(1):128151. DOI: 10.1002/bse.1989

Laurent, A, Bakas, I, Clavreul, J, Bernstad, A, Niero, M, Gentil, E, Hauschild, MZ, Christensen, TH. 2014. Review of LCA studies of solid waste management systems - Part I: Lessons learned and perspectives. Waste Management 34(3): 573-588. DOI: 10.1016/j.wasman.2013.10.045

Laurent, A, Owsianiak, M. 2017. Potentials and limitations of footprints for gauging environmental sustainability. Current Opinion in Environmental Sustainability 25: 20-27. DOI: 10.1016/j.cosust.2017.04.003

Lehman, A, Finkbeiner, M, Broadbent, C, Balzer, RT. 2015. Policy Options for Life Cycle Assessment Deployment in Legislation. In LCA Compendium - The Complete World of Life Cycle Assessment. Life Cycle Management, Sonnemann, G, Margni, M. (eds). Springer Netherlands. DOI: 10.1007/978-94-017-7221-1

Lozano, R, Nummert, B, Ceulemand, K. 2016. Elucidating the relationship between Sustainability Reporting and Organisational Change Management for Sustainability. Journal of Cleaner Production 125:158-188. DOI: 10.1016/j.jclepro.2016.03.021.

Martínez-Blanco, J, Inaba, A, Finkbeiner, M. 2016. Life Cycle Assessment of Organizations. In LCA Compendium - The Complete World of Life Cycle Assessment. Special Types of Life Cycle Assessments, Finkbeiner, M (ed). Springer Netherlands: Dordrecht. DOI: 10.1007/978-94-0177610-3

Masanet, E, Chang, Y. 2014. Who Cares About Life Cycle Assessment? A Survey of 900 Prospective Life Cycle Assessment Practitioners. Journal of Industrial Ecology 18(6): 787-791. DOI: $10.1111 /$ jiec. 12189

Mikler, JJ. 2007. Varieties of Capitalism and the Auto Industry's Environmental Initiatives: National Institutional Explanations for Firms' Motivations. Business and Politics 9(1): 1-38. DOI: 10.2202/1469-3569.1166

Milne, MJ, Gray, R. 2013. W(h)ither Ecology? The Triple Bottom Line, the Global Reporting Initiative, and Corporate Sustainability Reporting. Journal of Business Ethics 118(1): 13-29. DOI: $10.1007 / \mathrm{s} 10551-012-1543-8$

Molina-Murillo, SA, Smith, TM. 2009. Exploring the use and impact of LCA-based information in corporate communications. International Journal of Life Cycle Assessment 14(2):184-194. DOI: $10.1007 / \mathrm{s} 11367-008-0042-8$

Montabon, F, Sroufe, R, Narasimhan, R. 2007. An examination of corporate reporting, environmental management practices and firm performance. Journal of Operations Management 25(5): 9981014. DOI:10.1016/j.jom.2006.10.003

Nygren, J, Antikainen, R. 2010. Use of Life Cycle Assessment (LCA) in Global Companies. https://helda.helsinki.fi/bitstream/handle/10138/39723/SYKEre 16 2010.pdf?seque. [7 February 2018]

Owsianiak, M, Bjørn, A, Laurent, A, Molin, C, Ryberg, MW. 2018. LCA Applications. In Life Cycle 
Assessment. Theory and Practice, Hauschild, MZ, Rosenbaum, R, Olsen, SI (eds). Springer International Publishing: Cham. DOI: 10.1007/978-3-319-56475-3

PE International. 2014. Harmonization of LCA Methodologies for Metals A whitepaper providing guidance for conducting LCAs for metals and metal products. Version 1.0. Ottawa. Canada.

Pérez-López, D, Moreno-Romero, A, Barkemeyer, R. 2015. Exploring the Relationship between Sustainability Reporting and Sustainability Management Practices. Business Strategy and the Environment 24:720-734. DOI: 10.1002/bse.1841.

Pflieger, J, Fischer, M, Kupfer, T, Eyerer, P. 2005. The contribution of life cycle assessment to global sustainability reporting of organizations. Management of Environmental Quality 16(2): 167-179. DOI: $10.1108 / 14777830510583182$

Price Waterhouse Cooper (PWC) and Forest Products Association of Canada (FPAC). 2010. Life Cycle Assessment and Forest Products: A White Paper.

Roca, LC, Searcy, C. 2012. An analysis of indicators disclosed in corporate sustainability reports. Journal of Cleaner Production 20: 103-118. DOI:10.1016/j.jclepro.2011.08.002

Rosenblum, J, Horvath, A, Hendrickson, C. 2000. Environmental Implications of Service Industries. Environmental Science \& Technology 34(22): 4669-4676. DOI: 10.1021/es9914083

Santero, N, Hendry, J. 2016. Harmonization of LCA methodologies for the metal and mining industry. International Journal of Life Cycle Assessment 21:1543-1553. DOI: 10.1007/s11367-015-1022-4.

Schaltegger, S. 1997. Economics of life cycle assessment: inefficiency of the present approach. Business Strategy and the Environment 6:1-8. DOI: 10.1002/(SICI)10990836(199702)6:1<1::AID-BSE84>3.0.CO;2-D

Searcy, C, Buslovich, R. 2014. Corporate Perspectives on the Development and Use of Sustainability Reports. Journal of Business Ethics 121:149-169. DOI 10.1007/s10551-013-1701-7

SETAC: Fava, J, Denison, R, Jones, B, Curran, MA, Vigon, B, Selke, S, Barnum, J (eds). 1991. SETAC Workshop report: A Technical Framework for Life-Cycle Assessment. Smugglers Notch, Vermont, August 18-23 1990, SETAC Press.

Seuring, S. 2004. Industrial ecology, life cycles, supply chains: Differences and interrelations. Business Strategy and the Environment 13:306-319. DOI: 10.1002/bse.418.

Siew, RYJ. 2015. A review of corporate sustainability reporting tools (SRTs). Journal of Environmental Management 164: 180-195. DOI:10.1016/j.jenvman.2015.09.010

Sonnemann, G, Gemechu, ED, Sala, S, Schau, EM, Allacker, K, Pant, R, Adibi, N, Valdivia, S. 2018. Life Cycle Thinking and the Use of LCA in Policies Around the World. In Life Cycle Assessment. Theory and Practice, Hauschild, MZ, Rosenbaum, R, Olsen, SI (eds). Springer International Publishing: Cham. DOI: 10.1007/978-3-319-56475-3

Sousa, SR and Ometto, AR. 2011. Application of Life Cycle Assessment in Service Industries: a Review. Life Cycle Management Conference 2011.

De Souza, CG, Barbastefano, RG. 2011. Knowledge diffusion and collaboration networks on life cycle 
assessment. International Journal of Life Cycle Assessment 16(6): 561-568. DOI: $10.1007 / \mathrm{s} 11367-011-0290-\mathrm{x}$

Stewart, R, Owsianiak, M, Bjørn, A, Molin, C, Hauschild, MZ, Laurent, A. Life cycle assessment in corporate sustainability reporting: learnings from LCA use and guidance for a consistent reporting. (in preparation)

Talbot, D, Boiral, O. 2018. GHG Reporting and Impression Management: An Assessment of Sustainability Reports from the Energy Sector. Journal of Business Ethics 147:367-383. DOI: 10.1007/s10551-015-2979-4.

Testa, F, Nucci, S, Tessitore, S, Iraldo, F, Daddi, T. (2016) Perceptions on LCA implementation: evidence from a survey on adopters and nonadopters in Italy. International Journal of Life Cycle Assessment, 21(10): 1501-1513. DOI: 10.1007/s11367-016-1106-9.

The Sustainability Consortium. 2017. Our approach to product sustainability https://www.sustainabilityconsortium.org/about/\#av section 5 [7 February 2018]

Tregigda, H, Milne, M, Kearins, K. 2014. (Re)presenting 'sustainable organizations'. Accounting, Organizations and Society 39: 477-494. DOI: 10.1016/j.aos.2013.10.006.

Töpfer, K. 2002. Editorial for int J LCA on the launch of the UNEP-SETAC Life Cycle Initiative. The International Journal of Life Cycle Assessment 7(4): 191-191. DOI: 10.1007/BF02978871

United Nations. 2015. Transforming our world: the 2030 agenda for sustainable development A/RES/70/1 https://sustainabledevelopment.un.org/content/documents/21252030\%20Agenda\%20for\%20Sust ainable\%20Development\%20web.pdf [16 March 2018]

United Nations. 2017. Work of the Statistical Commission pertaining to the 2030 Agenda for Sustainable Development. http://ggim.un.org/meetings/2017-4th Mtg IAEG-SDGNY/documents/A RES 71 313.pdf [7 February 2018]

UNEP. 2015. Guidance on organizational life cycle assessment. Life-Cycle Initiative, United Nations Environment Programme and Society for Environmental Toxicology and Chemistry, Paris, http://www.lifecycleinitiative.org/resources/reports/

Wang, J, Tian, G, Fan, W, Luo, D. 2017. The effect of mandatory regulation on corporate social responsibility reporting quality: Evidence from China. Journal of Applied Business Research 33(1): 67-86. DOI: 10.19030/jabr.v33i1.9861

World Business Council for Sustainable Development (WBCSD). 2002. Sustainable development reporting. Striking the balance. http://wbcsdpublications.org/project/sustainable-developmentreporting-striking-the-balance/ [7 February 2018]

WBCSD Chemicals. 2014. Life Cycle Metrics for Chemical Products A guideline by the chemical sector to assess and report on the environmental footprint of products, based on life cycle assessment.

Weidema, BP, Thrane, M, Christensen, P, Schmidt, J, Løkke, S. 2008. Carbon footprint: A catalyst for life cycle assessment? Journal of Industrial Ecology 12(1): 3-6. DOI: 10.1111/j.1530- 


\section{$9290.2008 .00005 . x$}

Zamagni, A. 2012. Life cycle sustainability assessment. International Journal of Life Cycle Assessment 17:373-376. DOI 10.1007/s11367-012-0389-8 